\title{
Parental Knowledge of Dental Erosion and Erosion-Related Risk Factors in Children
}

\author{
Tanya Nihtyanova ${ }^{1}$, Plamena Sapunarova $^{1}$, Ani Belcheva-Krivorova ${ }^{2}$, Svetla Petrova ${ }^{1}$ \\ ${ }^{1}$ Department of Pediatric Dentistry, Faculty of Dental Medicine, Medical University of Plovdiv, Plovdiv, Bulgaria \\ ${ }^{2}$ Department of Prosthetic Dentistry, Faculty of Dental Medicine, Medical University of Plovdiv, Plovdiv, Bulgaria
}

Corresponding author: Tanya Nihtyanova, Department of Pediatric Dentistry, Faculty of Dental Medicine, Medical University of Plovdiv, Plovdiv, Bulgaria; E-mail: drnihtianova@gmail.com; Tel.: +359 898790249

Received: 26 June 2020 Accepted: 24 Nov 2020 Published: 31 Aug 2021

Citation: Nihtyanova T, Sapunarova P, Belcheva-Krivorova A, Petrova S. Parental knowledge of dental erosion and erosion-related risk factors in children. Folia Med (Plovdiv) 2021;63(4):541-5. doi: 10.3897/folmed.63.e55879.

\section{Abstract}

Introduction: Dental erosion in children has been steadily on the increase in recent years. This is mainly due to the contemporary eating habits of the new generations and their upbringing from an early age to prefer foods and beverages with high acid content.

Aim: To study the knowledge of parents about dental erosion and the most common risk factors associated with it.

Materials and methods: Data were gathered through a direct individual questionnaire administered to the parents of children aged 3 to 5 years. The results were analyzed by descriptive statistics and the Pearson chi-squared test for independence using SPSS 19.

Results: A large proportion of respondents (68.5\%) stated that they knew what dental erosion was. Most of them (77.4\%) were aware of the detrimental effect of carbonated beverages. In contrast, only $23.8 \%$ were aware of the potentially harmful effect of excessive consumption of citrus fruits, and only $31.9 \%$ of parents considered the impact of excessive intake of fruit juices. $16.1 \%$ of the participants were informed about the erosive potential of some medicines such as vitamin C. Nearly half of the parents (46.6\%) found vigorous tooth brushing damaging.

Conclusions: Despite the high self-esteem, a low percentage of the respondents were actually aware of the most common risk factors for dental erosion in children.

\section{Keywords}

dental erosion, risk factors, parental knowledge

\section{INTRODUCTION}

Erosion is defined as irreversible hard dental tissue loss as a result of the chemical action of exogenous or endogenous acids from a non-bacterial origin. During childhood, erosion is perceived as the main kind of tooth wear. ${ }^{1}$ Recently, the prevalence of dental erosion among children has been increasing. ${ }^{2}$ This is the result mainly of the contemporary eating habits, choice of food and drinks with high acidity and getting accustomed at an early age to preferring such food and drinks. ${ }^{3}$ Knowledge of the risk and protective factors for tooth erosion is essential for the prevention of this change during childhood and the possible complications later in life. Global scientific literature contains little data about the health awareness of patients of tooth erosion. ${ }^{4,5}$ There has been no previous research on this topic in Bulgaria. 


\section{AIM}

The aim of the study was to investigate parental knowledge about dental erosion and the most common etiological factors related to this condition among children.

\section{MATERIALS AND METHODS}

The data were gathered through an individual questionnaire. It was administered to parents of 3-5-year-old children included in a cross-sectional study. This study aimed to investigate the distribution and the risk factors for dental erosion among preschool children. A modified version of the O'Brien index (Survey of Children's Dental Health in the United Kingdom in the period 1992 -1997) was used for evaluation of dental erosion. The depth and area of involvement of the vestibular and lingual surface of upper incisors and the occlusal surface of the first molars of the primary dentition were assessed. The children participating in the study were randomly selected from the different kindergartens in Plovdiv they attended. They were included only after their parents signed an informed consent. The questionnaire contained questions concerning the dietary habits of the children and their parents' knowledge of the most common risk factors for dental erosion (according to the scientific literature data). We received 429 correctly filled-in questionnaires which were analyzed statistically. Distribution of parents according to their knowledge and of children according to their dietary habits was determined using an alternative analysis. The respondents were classified into "informed" and "not informed" groups according to the impact of the parental knowledge on the incidence of erosions among children. In the first cluster - "informed", we included parents holding the opinion that the relevant risk factor was potentially detrimental for tooth integrity, and the "not informed" cluster included parents with answers "don't know" and "it doesn't have any impact". For the data statistical analysis we used SPSS v.19. A value of $p<0.05$ was considered statistically significant.

\section{RESULTS}

The results showed that $68.53 \%$ of the parents stated that they knew what dental erosion was and only $31.47 \%$ admitted that they were not familiar with it. The question "Is it possible that the teeth of your child can be affected by the intake of citrus food?" was positively responded to only by one-fourth of the parents $(23.80 \%)$. The majority of the participants $(59.70 \%)$ thought that citrus fruits could not affect negatively their child's teeth and $16.60 \%$ answered "I don't know" (Table 1).

In compliance with these answers, $74.13 \%$ of the parents offered their children citrus fruits every day and $25.65 \%$ of the children consumed such foods twice or more per day. The analysis showed that the parental awareness of the impact of the excessive intake of citrus fruits was in a statistically significant association with the incidence of dental erosions $\left(\chi^{2}=6.19 ; p=0.01\right)$ (Fig. 1).

To the question "Is it possible that the teeth of your child can be affected by the intake of citrus juices?" only $31.93 \%$ of the parents answered with "Yes", 52.45\% thought that the citrus juices could not harm the teeth, and $15.62 \%$ could not answer this question (Table 1). The answers to the question "Do your child consume citrus drink or fresh juice every day?" showed that most of the children aged 3 to 5 didn't consume citrus drink daily, while one-third of the participants did (34.73\%). Of these, $10.02 \%$ consumed these drinks more than twice a day. The presence of erosions was in a statistically significant association with the parental knowledge of the erosive effect of the excessive intake of citrus juices $\left(\chi^{2}=6.56 ; p=0.01\right)$. The prevalence of erosions was higher among children whose parents thought that excessive drinking of citrus juices could not cause harm to the teeth (Fig. 2).

Most of the parents were informed about the damage carbonated drinks could cause to the teeth $(77.39 \%)$ (Table 1).

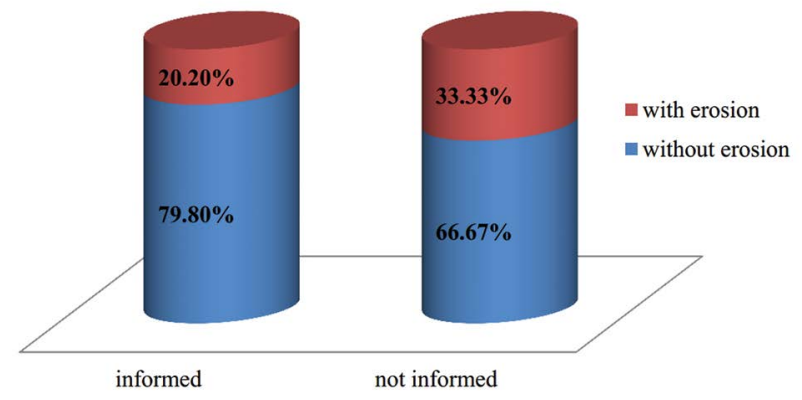

Figure 1. Distribution of children with erosions in accordance with their parents' knowledge of the potentially harmful effect of the citrus fruits excessive intake.

Table 1. Distribution of respondents according to the parental knowledge about the main risk factors for dental erosion

\begin{tabular}{lllll}
\hline Awareness of the impact of & $\begin{array}{l}\text { "Potentially harm- “Don't have any } \\
\text { ful impact" }\end{array}$ & $\begin{array}{l}\text { “I'm not } \\
\text { informed” }\end{array}$ & Total \\
\hline Excessive intake of citrus fruits & $102(23.78 \%)$ & $256(59.67 \%)$ & $71(16.55 \%)$ & $429(100 \%)$ \\
Excessive intake of citrus juices & $137(31.93 \%)$ & $225(52.45 \%)$ & $67(15.62 \%)$ & $429(100 \%)$ \\
Carbonated drinks & $332(77.39 \%)$ & $57(13.29 \%)$ & $40(9.32 \%)$ & $429(100 \%)$ \\
Vitamin C & $69(16.08 \%)$ & $281(65.50 \%)$ & $79(18.41 \%)$ & $429(100 \%)$ \\
Vigorous tooth brushing & $200(46.62 \%)$ & $170(39.63 \%)$ & $59(13.75 \%)$ & $429(100 \%)$ \\
\hline
\end{tabular}


In compliance with this, the majority of the respondents (68.06\%) didn't allow their children to have carbonated drinks. Despite the fact that the detrimental effect of these beverages on the teeth and the general health of children was well known ${ }^{6,7}$ and widely accepted, $9.32 \%$ of the parents still didn't know whether these drinks were harmful, and $13.29 \%$ were convinced that they didn't have any negative impact on teeth. In accordance with this, $9.33 \%$ of the parents offered their children carbonated drinks every day and $22.61 \%$ of them allowed their consumption, although not daily. The lack of knowledge of the harm of carbonated drinks was associated with increased incidence of dental erosion in children, though the results were not statistically significant $\left(\chi^{2}=3.10 ; p=0.08\right)$ (Fig. 3).

The majority of parents $(65.50 \%)$, even those who stated that they knew what dental erosion was (64.97\%), didn't consider vitamin $\mathrm{C}$ as potentially harmful for teeth (Table 1), but also most of the children didn't take vitamin $C$ daily (92.54\%). The analysis showed that the parental awareness of the erosive effect of vitamin $\mathrm{C}$ was in a statistically significant association with the incidence of erosions among children $\left(\chi^{2}=8.86 ; p=0.003\right)$ (Fig. 4).

According to the results of the survey, almost half of the parents $(53.38 \%)$ thought that vigorous brushing of teeth was not harmful or didn't know whether it was harmful (Table 1). The lack of parental knowledge about the impact of vigorous tooth brushing is associated with increased

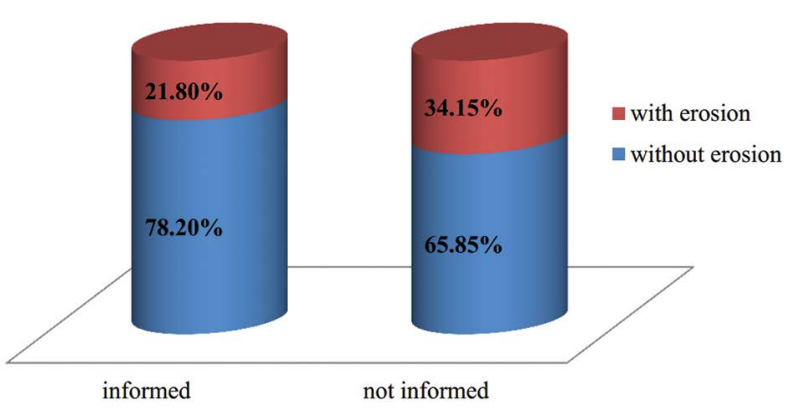

Figure 2. Distribution of children with erosion depending on their parents' knowledge of the potentially harmful effect of excessive consumption of citrus juices.

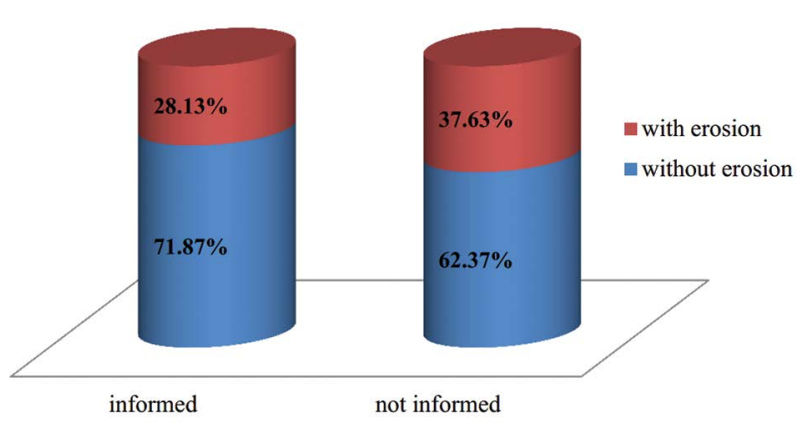

Figure 3. Distribution of children with erosion depending on their parents' knowledge of the harmful effect of carbonated drinks. incidence of erosion among children, without statistical significance $\left(\chi^{2}=1.96 ; p=0.16\right)$ (Fig. 5).

\section{DISCUSSION}

The incidence of tooth erosion has increased rapidly in the last decades ${ }^{8}$ mainly due to the changing eating habits and life style ${ }^{9}$. Many investigations link the dental erosion to the acids in the present diet. The most commonly found risk factors are the fruit and phosphoric acids that the fresh fruits, fruit juices, and carbonated drinks contained. ${ }^{10-13}$ The constant increase in these sources of acids intake, especially during childhood, is alarming. Even more disturbing is the lack of any knowledge on the part of the parents about the impact of the dietary habits on tooth integrity. ${ }^{4}$ The present study is in agreement with that. The majority of respondents stated that they were aware of the dental erosion, but at the same time the parents who were really aware of the most common risk factors were relatively few. The majority of parents were not informed that the excessive intake of citrus fruits and juices can have a negative impact on teeth.

The consumption of carbonated drinks in early childhood predisposes to unhealthy dietary habits later in childhood and adolescence ${ }^{14}$, and the role of the parents in choosing such beverages at this age is crucial ${ }^{4}$. The results

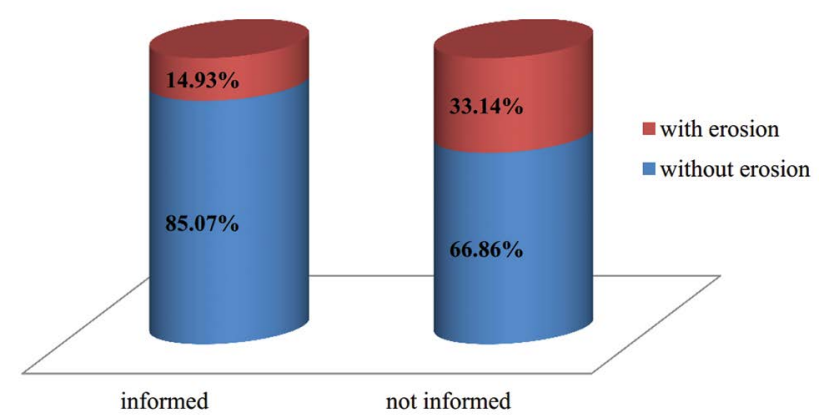

Figure 4. Distribution of children with erosion depending on their parents' knowledge of the potentially erosive effect of vitamin C on teeth.

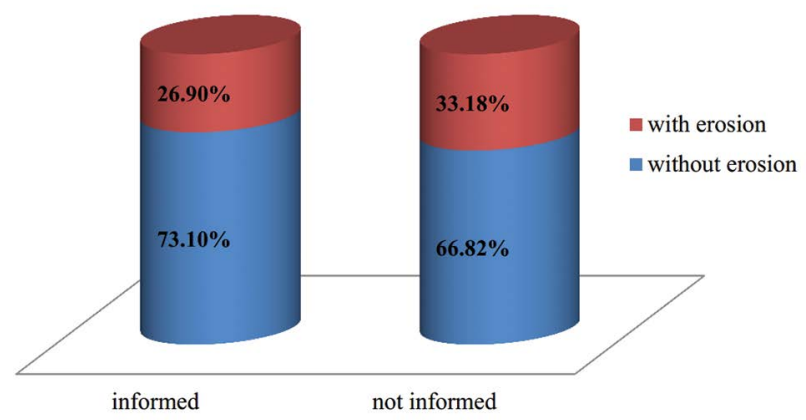

Figure 5. Distribution of children with dental erosion depending on their parental knowledge of the harmful effect of intensive tooth brushing. 
of the present study suggested that most of the parents were aware of the detrimental effect of carbonated drinks, but they barely linked this to dental erosions.

Some authors have found that the daily intake of vitamin $\mathrm{C}$ in a liquid form can be a risk factor for dental erosion. ${ }^{15,16}$ This conclusion is not supported by many studies, including the present study. This shows that the impact of vitamin $\mathrm{C}$ as a risk factor for tooth erosion is not widely acknowledged and it is reasonable that the majority of the parents are not aware of the potential harm that it can cause.

There is evidence showing that abrasion aggravates the dental erosion, which means that excessive brushing related to the frequency and increased pressure that is applied when brushing, combined with an intake of acidic food and drinks, leads to faster and more pronounced loss of hard dental tissue. ${ }^{17-19}$ Unfortunately, this study found that considerable part of the respondents was not aware of this fact.

\section{CONCLUSIONS}

The most common risk factors for dental erosion in childhood are increased intake of citrus fruits, fruit juices and carbonated beverages, especially in combination with excessive brushing of teeth, but this study showed that most parents are not aware of these factors and do not know the nature of dental erosion. It is necessary to enhance the parental knowledge about this increasingly serious problem of their children's oral health.

\section{REFERENCES}

1. Dugmore C, Rock W. A multifactorial analysis of factors associated with dental erosion. Br Dent J 2004; 196:283-6.

2. Aidi HE, Bronkhorst E, Huysmans M, et al. Dynamics of tooth erosion in adolescents: a 3-year longitudinal study. Journal of Dentistry 2010; 38(2):131-7.

3. Gambon D, Brand H, Veerman E. Dental erosion in the 21st century: what is happening to nutritional habits and lifestyle in our society? $\mathrm{Br}$ Dent J 2012; 213(2):55-7.

4. May J, Waterhouse P. Dental erosion and soft drinks: a qualitative assessment of knowledge, attitude and behaviour using focus groups of schoolchildren. A preliminary study. Int J Paediatr Dent 2003; 13(6):425-33.

5. Dugmore C, Rock W. Awareness of tooth erosion in 12 year old children and primary care dental practitioners. Community Dent Health 2003; 20(4):223-7.

6. Cheng R, Yang H, Chao M, et al. Dental erosion and severe tooth decay related to soft drinks: a case report and literature review. Journal of Zhejiang University 2009; 10(5):395-9.

7. Majewski R. Adolescent caries: a discussion on diet and other factors, including soft drink consumption. J Mich Dent Assoc 2001; 83(2):32-4.

8. Lussi A, Jaeggi T. Erosion - diagnosis and risk factors. Clin Oral Invest 2008; 12(1):5-13.

9. Lussi A, Schaffner M, Jaeggi T. Dental erosion - diagnosis and prevention in children and adults. Int Dent J 2007; 57(6):385-98.

10. Maharani DA, Pratiwi AN, Setiawati F, et al. Tooth wear among five-year-old children in Jakarta, Indonesia. BMC Oral Health 2019; 19(1):192.

11. Al-Dlaigan Y, Al-Meedania L, Anil S. The influence of frequently consumed beverages and snacks on dental erosion among preschool children in Saudi Arabia. Nutr J 2017; 16(1):80.

12. Richards D. Impact of diet on tooth erosion. Evid Based Dent 2016; 17(2):40.

13. Shahbaz U, Quadir F, Hosein T. Determination of prevalence of dental erosion in 12 - 14 years school children and its relationship with dietary habits. J Coll Physicians Surg Pak 2016; 26(7):553-6.

14. Gambon D, Brand H, Boutkabout $\mathrm{C}$, et al. Patterns in consumption of potentially erosive beverages among adolescent school children in the Netherlands. Int Dent J 2011; 61(5):247-51.

15. Chen Y, Li X, Hu D, et al. Prevalence of tooth erosion of 5-year-old and 12-year-old children in Xuzhou city. Hua Xi Kou Qiang Yi Xue Za Zhi 2009; 27:565-7.

16. Al-Malik M, Holt D, Bedi R. The relationship between erosion, caries and rampant caries and dietary habits in preschool children in Saudi Arabia. Int J Paediatr Dent 2001; 11:430-9.

17. Lussi A, Jaeggi T. Dental Erosion. Diagnosis, risk assessment, prevention, treatment. London: Quintessence Publishing; 2011.

18. Ponduri S, Macdonald E, Addy M. A study in vitro of the combined effects of soft drinks and tooth brushing with fluoride toothpaste on the wear of dentine. Int J Dent Hyg 2005; 3(1):7-12.

19. Rios D, Honorio H, Magalhães A, et al. Influence of toothbrushing on enamel softening and abrasive wear of eroded bovine enamel: an in situ study. Braz Oral Res 2006; 20(2):148-54. 


\title{
Осведомлённость родителей относительно стоматологической эрозии и связанных с ней фракторами риска у детей
}

\author{
Таня Нихтянова ${ }^{1}$, Пламена Сапунарова ${ }^{1}$, Ани Белчева-Криворова ${ }^{2}$, Светла Петрова $^{1}$ \\ ${ }^{1}$ Кафедра детской стоматологии, Факультет дентальной медицины, Медицинский университет - Пловдив, Пловдив, Болгария \\ ${ }^{2}$ Кафедра ортопедической стоматологии, Факультет дентальной медицины, Медицинский университет - Пловдив, Пловдив, Болгария
}

Адрес для корреспонденции: Таня Нихтянова, Кафедра детской стоматологии, Факультет дентальной медицины, Медицинский университет - Пловдив, Пловдив, Болгария; E-mail: drnihtianova@gmail.com; Тел.: +359 898790249

Дата получения: 26 июня 2020 Дата приемки: 24 ноября 2020 Дата публикации: 31 августа 2021

Образец цитирования: Nihtyanova T, Sapunarova P, Belcheva-Krivorova A, Petrova S. Parental knowledge of dental erosion and erosion-related risk factors in children. Folia Med (Plovdiv) 2021;63(4):541-5. doi: 10.3897/folmed.63.e55879.

\section{Резюме \\ Введение: Эрозия зубов у детей в последние годы неуклонно растёт. В основном это связано с современными пищевыми привычками новых поколений, и их привычки с раннего возраста отдают предпочтение продуктам и напиткам с очень кис- лым составом.}

Цель: Изучить осведомлённость родителей об эрозии зубов и наиболее распространённых факторах риска, связанных с ней.

Материалы и методы: Данные были собраны с помощью прямого индивидуального опроса, проведённого среди родителей детей в возрасте от 3 до 5 лет. Результаты были проанализированы с использованием описательной статистики и теста независимости хи-квадрат Пирсона с SPSS 19.

Результаты: Большая часть респондентов (68.5\%) заявили, что знают, что такое эрозия зубов. Большинство из них (77.4\%) знали о вредном воздействии газированных напитков. Напротив, только $23.8 \%$ знали о потенциально вредных последствиях чрезмерного употребления цитрусовых, и только $31.9 \%$ родителей учитывали воздействие чрезмерного потребления фруктового сока. 16.1\% участников были осведомены об эрозийном потенциале некоторых лекарств, таких как витамин С. Почти половина родителей $(46.6 \%)$ считают сильную чистку зубов вредной.

Заключение: Несмотря на высокую самооценку, небольшой процент респондентов действительно знал о наиболее распространённых факторах риска эрозии зубов у детей.

\section{Ключевые слова}

эрозия зубов, факторы риска, осведомлённость родителей 